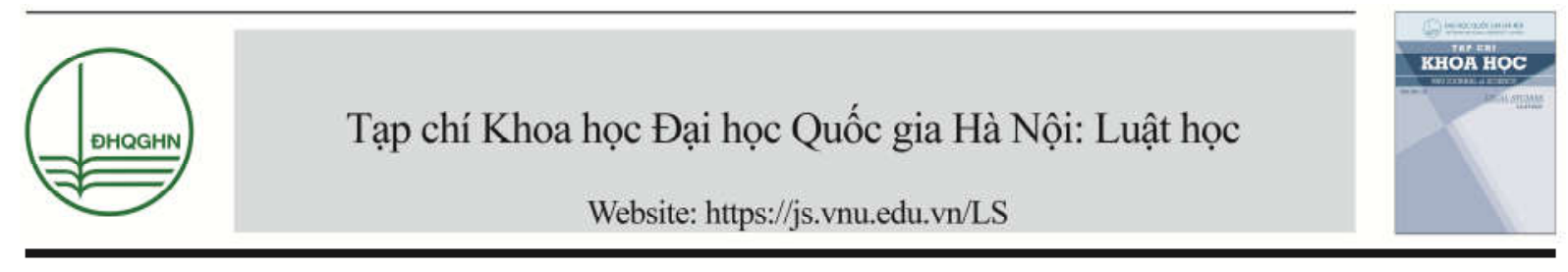

\title{
Tiếp cận công lý và vấn đề hoàn thiện cơ chế bảo hiến ở Việt Nam
}

\author{
Đặng Minh Tuấn* \\ Khoa Luật, Đại học Quốc gia Hà Nội, 144 Xuân Thủy, Cầu Gián, Hà Nội, Việt Nam \\ Ngày nhận 21 tháng 3 năm 2018 \\ Chỉnh sửa ngày 23 tháng 3 năm 2018; Chấp nhận đăng ngày 23 tháng 3 năm 2018
}

Tóm tắt: Bảo hiến là một chủ đề đã được thảo luận nhiều ở nước ta trong những năm gần đây, nhưng hầu như chưa được nghiên cứu dưới góc độ tiếp cận công lý. Bài viết này phân tích một số vấn đề chung về mối quan hệ giữa tiếp cận công lý và bảo hiến, từ đó đánh giá những hạn chế, khó khăn, triển vọng và đề xuất một số giải pháp bảo đảm quyền tiếp cận công lý thông qua cơ chế bảo hiến ở Việt Nam.

Từ khóa: Tiếp cận công lý, bảo hiến, tài phán hiến pháp, Hiến pháp Việt Nam.

\section{Tiếp cận công lý và bảo hiến}

Tiếp cận công lý được hiểu là khả năng tìm kiếm sự đền bù/khắc phục cho những bất công hay thiệt hại cho một cá nhân hay một nhóm cá nhân, đặc biệt là cho những nhóm dễ bị tổn thương phải gánh chịu. Việc tìm kiếm sự đền bù/khắc phục được thực hiện thông qua việc tiếp cận với các thiết chế tư pháp, giám sát (công quyền) và các thiết chế xã hội (cơ chế hòa giải cộng đồng). Tiếp cận công lý được bảo đảm dựa trên các nền tảng cơ bản sau: khuôn khổ các quyền và nghĩa vụ pháp lý; khuôn khổ thể chế (các cơ quan tư pháp, cơ quan giám sát, cơ quan hòa giải...); khả năng đòi hỏi và theo đuổi vụ việc của người dân (sự hiểu biết pháp

\footnotetext{
* ĐT.: 84-978796682.

Email: tuandangvnu@gmail.com

https://doi.org/10.25073/2588-1167/vnuls.4144
}

luật, vai trò của các cơ quan trợ giúp, tư vấn pháp luật) [1].

Bảo hiến là một cơ chế bảo đảm quyền tiếp cận công lý. Mối quan hệ này thể hiện ở khuôn khổ các quyền và nghĩa vụ hiến định, cơ chế bảo hiến và khả năng người dân trong vụ việc hiến pháp.

\section{Về khuôn khổ các quyền và nghĩa vu}

Các quyền con người được quy định trong Hiến pháp là các quyền con người cơ bản nhất, cốt lõi nhất đặt nền tảng cho việc ghi nhận và bảo vệ các quyền con người cụ thể trong các đạo luật và các văn bản pháp luật khác. Trên cơ sở các quy định của Hiến pháp, các cá nhân, công dân được hưởng các quyền cơ bản, và đồng thời Nhà nước có trách nhiệm tôn trọng, bảo vệ và bảo đảm các quyền con người đó. Khi các quyền con người cơ bản bị vi phạm, Nhà nước cần có cơ chế để xem xét, xử lý các hành vi vi phạm và 
phục hồi các quyền con người cho các cá nhân, công dân bị vi phạm. Bảo hiến là cơ chế bảo vệ các quyền con người, quyền cơ bản của công dân được ghi nhận trong Hiến pháp [2].

\section{Về khuôn khổ thể chế}

Với tính cách là cơ chế xử lý các hành vi phạm Hiến pháp, nhiều cơ quan nhà nước có thể được trao thẩm quyền bảo hiến. Tuy nhiên, các tòa án đóng vai trò cơ bản, quan trọng nhất trong việc thực hiện chức năng bảo vệ Hiến pháp, xử lý các vi phạm công quyền đối với các quyền con người, quyền công dân được Hiến pháp ghi nhận [3]. Trong các mô hình, việc trao quyền cho Tòa án hiến pháp hoặc các tòa án thẩm quyền chung là hai mô hình phổ biến nhất [4]. Ngoài ra, Hội đồng hiến pháp là một mô hình bảo hiến hạn chế, nhưng ở một số nước, thiết chế này đang dần chuyển sang một Tòa án hiến pháp độc lập thực hiện chức năng tài phán hiến pháp [5]. Để thực hiện chức năng của cơ quan tài phán hiến pháp là xử lý các vi phạm của các cơ quan công quyền, kể Nghị viện, người đứng đầu hành pháp hay những cá nhân, tổ chức quyền lực khác trong bộ máy nhà nước, cơ quan tài phán cần phải có vị thế được nhà nước, xã hội ghi nhận và đề cao, có vị trí độc lập và có đủ thẩm quyền xử lý các vi phạm Hiến pháp.

\section{Về khả năng của người dân}

Trong các vụ việc hiến pháp, người dân thách thức các hành vi của các cá nhân, tổ chức quyền lực trong bộ máy nhà nước, do vậy họ cũng gặp rất nhiều khó khăn, thách thức để có thể thắng trong vụ kiện, bảo vệ được các quyền và lợi ích hợp hiến của mình. Để thực hiện được điều đó, người dân cần có khả năng, năng lực chủ thể đầy đủ để tiếp cận và theo đuổi vụ việc. Trước hết, họ phải nhận thức đầy đủ, đúng đắn về các quyền hiến định, đồng thời hiểu và có khả năng sử dụng các thủ tục, cơ chế bảo hiến để bảo vệ các quyền của mình [6]. Vụ việc hiến pháp thường là những vụ việc phức tạp, nhậy cảm và chịu nhiều tác động của các yếu tố chính trị, do vậy các cơ quan quan trợ giúp, tư vấn pháp luật, luật sư và các tổ chức cộng đồng cũng đóng vai trò quan trọng trong việc hướng dẫn, giúp đỡ người dân trong việc bảo vệ các quyền của họ.

\section{Những hạn chế, khó khăn trong việc bảo đảm quyền tiếp cận công lý thông qua cơ chế bảo hiến ở nước ta}

Dưới góc độ tiếp cận công lý, có thể chỉ ra các hạn chế sau đây liên quan đến các quy định của Hiến pháp về quyền con người, quyền công dân, cơ chế bảo hiến hiện hành cũng như năng lực, nhận thức của người dân về Hiến pháp, về các quyền con người, quyền công dân ở nước ta.

\subsection{Hạn chế của các quy định Hiến pháp về quyền con người, quyền công dân}

Hiến pháp năm 2013 với các quy định ở Chương 2 - Quyền con người, quyền và nghĩa vụ cơ bản của công dân thể hiện một bước tiến quan trọng trong việc ghi nhận các quyền con người, quyền cơ bản của công dân phù hợp với các chuẩn mực pháp luật quốc tế về quyền con người. Bên cạnh đó, Hiến pháp 2013 vẫn còn một số điểm hạn chế, bất cập nhất định liên quan đến bảo đảm quyền tiếp cận công ý thông qua cơ chế bảo hiến.

Cách quy định (hình thức) của các quy phạm Hiến pháp chưa thực sự thống nhất, khi các cụm từ việc thực hiện các quyền "do pháp luật quy dịnh", "luật định" được sử dụng thay thế nhau. Hơn nữa, khái niệm "pháp luật" có nội hàm rất rộng, không chỉ là luật của Quốc hội, mà còn bảo gồm nhiều các văn bản quy phạm pháp luật của các cơ quan nhà nước khác. Quy định trao cho các cơ quan nhà nước từ trung ương xuống địa phương quyền quy định, cụ thể hóa các quyền hiến định vẫn có thể mở đường cho thực trạng hiện nay là các quyền hiến định của người dân bị hạn chế một cách khá tùy tiện bởi các quy phạm pháp luật cấp thấp (do chưa có luật điều chỉnh) cho dù Hiến pháp đã quy định các quyền con người, quyền công dân chỉ có thể bị hạn chế bằng luật và trong các trường hợp cần thiết (Khoản 2 Điều 
14 Hiến pháp năm 2013). Xét ở phương diện thực thi Hiến pháp, quy định việc thực hiện các quyền "do pháp luật quy định", "luật định" cũng có thể làm cho Hiến pháp trở nên hình thức, bởi vì các quyền hiến định không thể được thực thi nếu thiếu các văn bản pháp luật cụ thể hóa. Công dân có quyền tự do ngôn luận, tự do thông tin, hội họp, lập hội và biểu tình, nhưng các quyền này không thể được đảm bảo trên thực tiễn bởi vì chưa có luật thực thi các quyền này. Nếu Hiến pháp lược bỏ quy phạm "do pháp luật quy định", thì các quyền hiến định phải được áp dụng một cách trực tiếp, mà chưa cần phải có các quy phạm dưới Hiến pháp quy định. Người dân có quyền khiếu nại, khiếu kiện các cơ quan nhà nước có thẩm quyền bảo vệ các quyền hiến định thiêng liêng của mình [7].

Những nỗ lực xác định phân biệt các quyền của "mọi người" và quyền của "công dân" có nhiều ý nghĩa trong tư duy và thực tiễn bảo vệ quyền con người, quyền công dân. Tuy vậy, ngoài một số ít quyền chỉ dành cho công dân như quyền bầu cử, ứng cử, tham gia quản lý nhà nước, các quyền khác đều là quyền của tất cả mọi người. Tuy nhiên, Hiến pháp mới vẫn giới hạn rất nhiều quyền chỉ dành riêng cho công dân: Quyền có nơi ở hợp pháp (Điều 22); Quyền tự do đi lại và cư trú (Điều 23); Quyền tự do ngôn luận, tự do báo chí, tiếp cận thông tin, hội họp, biểu tình (Điều 25); Quyền bình đẳng giới (Điều 26); Quyền kiến nghị với các cơ quan nhà nước (Điều 28); Quyền được đảm bảo an sinh xã hội (Điều 34); Quyền được làm việc, lựa chọn nghề nghiệp, việc làm và nơi làm việc (Điều 35$)$. Khi xem xét các quyền này, ta có thể nhận thấy rằng không chỉ có công dân Việt Nam, mà mọi người (không phân biệt quốc tịch) đều có hưởng các quyền và được pháp luật bảo vệ, mặc dù điều kiện, quy trình, thủ tục bảo đảm các quyền cơ bản này của công dân và những người không phải là công dân có thể khác nhau. Các quy định như thế này đã hạn chế quyền tiếp cận công lý của người nước ngoài, người không quốc tịch [8].

\subsection{Han chế của cơ chế bảo hiến hiên hành}

Hiến pháp năm 2013 về cơ bản tiếp tục duy trì cơ chế bảo hiến truyền thống ${ }^{1}$ và không ghi nhận thêm bất kỳ một cơ chế bảo hiến mới nào. Cơ chế bảo hiến hiện nay có nhiều điểm hạn chế, khó có thể phát huy vai trò, thể hiện ở các phương diện sau đây:

\section{Bảo hiến không chuyên trách và thiếu tài phán tu pháp}

Hiến pháp năm 2013 trao trách nhiệm bảo hiến cho nhiều cơ quan nhà nước ${ }^{2}$, trong đó Quốc hội và cơ quan thường trực của nó đóng vai trò trung tâm trong cơ chế bảo hiến, thực hiện quyền giám sát tối cao việc tuân theo Hiến pháp ${ }^{3}$. Trong các cơ quan, tòa án cũng được nhắc đến là cơ quan có trách nhiệm bảo vệ Hiến pháp, tuy nhiên Hiến pháp và các đạo luật về ngành tư pháp không quy định thẩm quyền đáng kể của các tòa án trong hoạt động bảo vệ Hiến pháp ${ }^{4}$. Trên thực tế, Tòa án cũng chưa bao giờ viện dẫn Hiến pháp để xét xử, giải thích Hiến pháp hay xem xét tính hợp hiến của một đạo luật hay quy phạm pháp luật.

\footnotetext{
${ }^{1}$ Mô hình bảo hiến truyền thống là mô hình bảo hiến của Nhà nước Xã hội Chủ nghĩa được ghi nhận từ Hiến pháp năm 1959, sau đó được ghi nhận lại ở các bản Hiến pháp sau này.

${ }^{2}$ Khoản 2 Điều 119 của Hiến pháp năm 2013 quy định: "Quốc hội, các co quan của Quốc hội, Chủ tịch nước, Chính phủ, Tòa án nhân dân, Viện kiểm sát nhân dân, các co quan khác của Nhà nước và toàn thể Nhân dân có trách nhiệm bảo vệ Hiến pháp. Co chế bảo vệ Hiến pháp do luật định".

3 "Quốc hộ bãi bỏ văn bản của Chủ tịch nước, Uỷ ban thường vu Quốc hội, Chính phủ, Thủ tuoóng Chính phủ, Toà án nhân dân tối cao, Viện kiểm sát nhân dân tối cao trái với Hiến pháp, luật, nghi quyết của Quốc họi (Khoản 10 Điều 70 Hiến pháp năm 2013); Ủy ban thuờng vu Quốc hội đình chỉ việc thi hành văn bản của Chính phủ, Thủ tuóng Chính phủ, Toà án nhân dân tối cao, Viện kiểm sát nhân dân tối cao trái với Hiến pháp, luật, nghi quyết của Quốc hội và trình Quốc hội quyết định việc bãi bỏ văn bản đó tại kỳ họ gần nhất; bãi bỏ văn bản của Chính phủ, Thủ tuớng Chính phủ, Toà án nhân dân tối cao, Viện kiểm sát nhân dân tối cao trái với pháp lệnh, nghị quyết của Uỷ ban thuoờng vu Quốc hộ" (Khoản 4 Điều 74 Hiến pháp năm 2013).

4 Khi xem xét thấy có văn bản pháp luật trái Hiến pháp,Tòa án không có quyền đình chỉ, bãi bỏ văn bản đó mà chỉ quyền kiến nghị các cơ quan nhà nước có thẩm quyền xem xét để xử lý.
} 
Sự thiếu vắng bảo hiến chuyên trách và tài phán tư pháp là một hạn chế lớn của cơ chế bảo hiến hiện nay của Việt Nam. Quốc hội - với tính chất là cơ quan chính trị quốc gia cùng các cơ quan nhà nước không chuyên khác không thể thực hiện hiệu quả vai trò bảo hiến.

\section{Co chế tụ kiểm soát lập pháp}

Kiểm soát lập pháp hiện nay là là cơ chế tự kiểm soát, bởi theo quy định của Hiến pháp và pháp luật hiện hành, Quốc hội là cơ quan duy nhất có quyền kiểm tra tính hợp hiến của luật thông qua việc thực hiện quyền lập pháp (làm luật, sửa đổi luật). Quy định "Quốc hội là $c o$ " quan quyền lực cao nhất của Nước Cộng hòa Xã hội Chủ nghĩa Việt Nam" ở Điều 69 Hiến pháp năm 2013 được coi là cơ sở để trao quyền duy nhất cho Quốc hội (chứ không phải là một cơ quan bảo hiến độc lập nào khác) có quyền kiểm tra tính hợp hiến của luật. Tuy nhiên, cơ chế tự kiểm soát mang tính nội bộ của cơ quan lập pháp, nằm trong nội dung quyền lập pháp, chứ chưa phải là cơ chế kiểm soát quyền lực đúng nghĩa (kiểm soát lẫn nhau giữa các cơ quan nhà nước).

Chura ghi nhận quyền khiếu nại, khiếu kiện hiến pháp của công dân

Để hiện thực hóa các quyền hiến định của nhân dân, khi các quyền cơ bản bị vi phạm, công dân cần có quyền khiếu nại, khiếu kiện lên cơ quan bảo vệ Hiến pháp. Tuy vậy, các quy định pháp luật hiện hành không trao cho người dân có quyền khởi kiện, khiếu nại các vi phạm Hiến pháp. Điều này hạn chế căn bản những chủ thể bị vi phạm có quyền yêu cầu các cơ quan nhà nước có thẩm quyền xem xét các vi phạm hiến pháp đối với các quyền con người, quyền cơ bản công dân của họ.

Trong khi đó, Hiến pháp và pháp luật hiện hành đặt cược vào quyền đề xuất xử lý các vi phạm hiến pháp vào các cơ quan nhà nước. Chưa kể chỉ một số ít chủ thể (cơ quan nhà nước) có quyền đề xuất vụ việc hiến pháp và các đề xuất phải được kiểm duyệt thông qua nhiều bộ lọc khác nhau trước khi trình lên các cơ quan nhà nước có thầm quyền xem xét, xử lý. Trên thực tế, hoạt động của các cơ quan nhà nước thường chịu ảnh hưởng rất lớn bởi các yếu tố chính trị, đặc biệt đặt dưới sự lãnh đảo của Đảng Cộng sản Việt Nam. Những quy định và thực tiễn như vậy dẫn đến tình trạng hầu như không có đề xuất nào được đưa ra hoặc có đề xuất nhưng đều dừng lại ở một khâu nào đó trước khi được các cơ quan nhà nước có thẩm quyền xem xét, xử lý.

\section{Thiếu quy trình, thủ tục đầy đủ, chặt chẽ}

Pháp luật hiện hành chủ yếu quy định về thẩm quyền giải quyết, hậu quả pháp lý của các quyết định nhưng chưa quy định chi tiết, cụ thể về quy trình, thủ tục, phương pháp, thời hạn, điều kiện bảo đảm các hoạt động bảo hiến. Pháp luật hiện hành cũng không xác định rõ trách nhiệm của các chủ thể bảo hiến trong việc xem xét, giải quyết các đề xuất được đưa lên [8].

Những bất cập của cơ chế bảo hiến ở nước ta dẫn đến thực trạng vai trò mờ nhạt, hạn chế của cơ chế bảo hiến trong việc bảo vệ Hiến pháp, đồng nghĩa với việc các cá nhân, tổ chức không có cơ hội tiếp cận được một cơ chế bảo hiến có khả năng xử lý các vi phạm Hiến pháp, vi phạm các quyền con người, quyền cơ bản của công dân được Hiến pháp ghi nhận. Trên thực tế, không ít các văn bản pháp luật, các quyết định của cả cơ quan lập pháp, hành pháp và chính quyền địa phương các cấp đã có dấu hiệu vi phạm Hiến pháp, vi phạm các quyền cơ bản của công dân [9]. Xuất phát từ thực trạng đó, trong những năm gần đây, đặc biệt thời kỳ xây dựng Hiến pháp năm 2013, xây dựng tài phán hiến pháp được quan tâm rất lớn trong giới khoa học cũng như các nhà lãnh đạo. Tuy nhiên, xây dựng tài phán hiến pháp ở Việt Nam có nhiều lực cản xuất phát từ truyền thống chính trị, triết lý tổ chức bộ máy nhà nước, những hạn chế của chính hệ thống tư pháp và một số yếu tố khác.

\subsection{Hạn chế về nhận thức của người dân}

Bên cạnh cơ chế bảo hiến, thì nhận thức, sự hiểu biết của người dân về Hiến pháp nói chung và các quyền con người, quyền công dân được ghi nhận trong Hiến pháp nói riêng có vai trò 
quan trọng trong việc bảo đảm quyền tiếp cận công lý của người dân. Hiến pháp quy định các quyền con người, quyền cơ bản của công dân, nhưng việc tiếp cận, sử dụng Hiến pháp để bảo vệ quyền con người, quyền công dân phụ thuộc rất lớn vào nhận thức của người dân về các quyền hiến định, về các cơ chế, thủ tục được Hiến pháp, pháp luật ghi nhận để bảo vệ, thực thi các quyền của họ.

Thực tế thì hiện nay nhận thức của người dân về Hiến pháp, về các quyền con người, quyền cơ bản của công dân, về các cơ chế hiến định còn hạn chế. Như theo phản ánh của người dân sau một thời gian thi hành Hiến pháp năm 2013, nhiều người dân vẫn chưa biết Hiến pháp mới như thế nào [10]. Nguyên nhân cơ bản của tình trạng này là sự thờ $o$, thiếu quan tâm của người dân về Hiến pháp xuất phát chính từ việc người dân không thể sử dụng trực tiếp được Hiến pháp, thiếu cơ chế bảo hiến hữu hiệu để người dân có thể sử dụng để bảo vệ các quyền hiến định khi bị vi phạm. Ngoài ra, việc tuyên truyền, phổ biến và giáo dục Hiến pháp ở nước ta cũng còn nhiều bất cập, hạn chế [11-12].

\section{Triển vọng, giải pháp bảo đảm quyền tiếp cận công lý thông qua cơ chế bảo hiến}

3.1. Hiến pháp năm 2013 lần đầu tiên xác định rõ và đầy đủ các nghĩa vụ của nhà nước trong việc "công nhận, tôn trong, bảo vệ và bảo đảm quyền con người, quyền công dân" (Điều 3 và Điều 14 khoản 1). Quy định mới này phản ánh sự thay đổi tư duy trước đây ở Việt Nam coi quyền con người, quyền công dân là những thứ nhà nước "ban phát" cho người dân, sang nhận thức chung của cộng đồng quốc tế trong đó xem quyền con người, quyền công dân là những giá trị tự nhiên, vốn có của con người mà nhà nước có nghĩa vụ ghi nhận và bảo đảm. Đồng thời, Hiến pháp năm 2013 bổ sung một nguyên tắc hiến định, đó là quyền con người, quyền công dân chỉ có thể bị hạn chế theo quy định của luật trong trường hợp cần thiết vì lý do quốc phòng, an ninh quốc gia, trật tự, an toàn xã hội, đạo đức, sức khỏe của cộng đồng (Điều
14, khoản 2). Nguyên tắc này có ý nghĩa quan trọng trong việc ngăn ngừa các cơ quan nhà nước tùy tiện giải thích và hạn chế các quyền hiến định mà đã xảy ra khá nhiều ở Việt Nam, bởi nó nêu rõ những lý do có thể được sử dụng để hạn chế quyền, cùng với việc giới hạn chủ thể duy nhất là Quốc hội mới có thể quyết định việc này (bằng luật), chứ không phải bất cứ cơ quan nhà nước nào (bằng pháp luật ${ }^{5}$ ) như trong Hiến pháp năm 1992. Ngay cả Quốc hội cũng không phải tuân thủ các quy định của Điều 14 khoản 2 về giới hạn quyền con người. Ngoài ra, có quan điểm còn cho rằng, nguyên tắc này còn có ý nghĩa là các quy định liên quan đến các quyền bất khả xâm phạm của con người, của công dân (như quyền được sống, quyền không bị tra tấn, quyền bình đẳng trước pháp luật v.v.) là có hiệu lực trực tiếp; chủ thể của các quyền này được viện dẫn các quy định của Hiến pháp để bảo vệ các quyền của mình khi bị xâm phạm [13].

3.2. Hiến pháp năm 2013 lần đầu tiên bổ sung nguyên tắc kiểm soát quyền lực nhà nước: "Quyền lực nhà nước là thống nhất, có sự phân công, phối hợp, kiểm soát giữa các cơ quan nhà nước trong việc thực hiện các quyền lập pháp, hành pháp, tư pháp" (Điều 2$)^{6}$. Đây là điểm mới rất quan trọng trong chế định về thể chế chính trị của Hiến pháp năm 2013. Nó cho thấy Việt Nam đã tiến thêm một bước nữa trong việc vận dụng các thuộc tính của nguyên tắc phân quyền, nhưng vẫn chưa chính thức thừa nhận nguyên tắc này. Với quy định mới đã nêu, kiểm soát quyền lực đã được thừa nhận là một nguyên tắc của nhà nước pháp quyền, là một vấn đề mới trong tổ chức quyền lực nhà nước ở Việt Nam, được thể hiện xuyên suốt trong các Chương V, VI, VII, VIII và IX của Hiến pháp năm 2013 và sẽ tiếp tục được thể chế hóa trong các luật có liên quan.

\footnotetext{
5 Ở Việt Nam, khái niệm pháp luật được hiểu theo nghĩa rộng, bao gồm tất cả các văn bản quy phạm pháp luật do các cơ quan nhà nước từ trung ương đến địa phương ban hành. Còn luật thì chỉ có thể do Quốc hội thông qua.

${ }^{6}$ Hiến pháp năm 1992 (Điều 2) chỉ quy định: "Quyền lục nhà nước là thống nhất, có sụ phân công và phối hợp giũa các cơ quan nhà nước trong việc thực hiện các quyền lập pháp, hành pháp, tu pháp".
} 
3.3. Điều 119 Hiến pháp năm 2013 kế thừa quy định "Hiến pháp là luật co bản của nước CHXHCN Việt Nam, có hiệu lực pháp lý cao nhất. Moi văn bản pháp luật khác phải phù hơp với Hiến pháp" như Điều 146 Hiến pháp năm 1992, nhưng bổ sung quy định mới: "Mọi hành vi vi phạm Hiến pháp đều bị xư lý" và xác định rõ "Quốc hội, các cơ quan của Quốc hội, Chủ tịch nước, Chính phủ, TAND, VKSND, các cơ quan khác của Nhà nước và toàn thể Nhân dân có trách nhiệm bảo vệ Hiến pháp". Các quy định này đặt cơ sở thiết lập một cơ chế tài phán (bao gồm tài phán tư pháp) đối với các vi phạm Hiến pháp, kể cả luật, nghị quyết của Quốc hội. Mặc dù không có quy định mới về cơ chế bảo hiến, nhưng Hiến pháp năm 2013 đã mở ra cơ hội lớn cho việc nghiên cứu đề xuất, nghiên cứu cơ chế bảo hiến cụ thể khi quy định: "Cơ chế bảo vệ Hiến pháp do luật định" (Khoản 2 Điều 119). Đây có thể là một giải pháp có tính chất tình thế khi các nhà lập hiến chưa tìm được một sự đồng thuận về một cơ chế bảo hiến cụ thể trong Hiến pháp và để vấn đề này cho luật quy định.

3.4. Trong việc nghiên cứu tìm kiếm một mô hình bảo hiến, cần nghiên cứu các mô hình và đặt trong bối cảnh ở Việt Nam để có những điều chỉnh phù hợp. Theo cách tiếp cận công lý mới, thì các cơ chế, phương thức tư pháp chính thống (tòa án), phi chính thống hay các cơ chế giám sát đều có những vai trò khác nhau trong việc bảo đảm quyền tiếp cận công lý.

Phương án thành lập Hội đồng Hiến pháp không được chấp nhận trong Hiến pháp năm 2013, nhưng đề xuất này vẫn được coi là một trong những lựa chọn có tính khả thi và phù hợp trong bối cảnh chính trị và tổ chức quyền lực nhà nước ở Việt Nam. Có lẽ vấn đề trung tâm chỉ là cần thảo luận làm rõ, củng cố vị trí, vai trò của thiết chế này trong khi chờ đợi các chính trị giá nhận thức đầy đủ về vai trò của bảo hiến trong xã hội dân chủ và pháp quyền.

Một trong những giải pháp tốt là công nhận và thúc đẩy vai trò của các tòa án trong hoạt động bảo hiến. Tòa án hoàn toàn thể được trao thẩm quyền kiểm tra tính hợp hiến của lập pháp, hành pháp, bởi vì bảo hiến gắn liền với chức năng xét xử của tòa án. Kiểm tra tính hợp hiến các hành vi công quyền cũng là xét xử một loại vụ việc hiến pháp. Trong xét xử, Tòa án cũng phù hợp với vai trò giải thích Hiến pháp, luật để giải quyết một vụ việc cụ thể, bởi vì Tòa án không thể áp dụng Hiến pháp, luật nếu không giải thích Hiến pháp, luật. Đặc điểm cơ bản của cơ chế tài phán, giải thích Hiến pháp của tòa án là ở chỗ tòa án bảo vệ Hiến pháp, giải thích Hiến pháp trong một vụ việc cụ thể, theo thủ tục tư pháp (khác với bảo hiến trừu tượng, giải thích Hiến pháp trừu tượng như thẩm quyền giải thích Hiến pháp trừu tượng của UBTVQH) [14]. Thành lập Tòa án hiến pháp được cho là đề xuất tiến bộ và phù hợp với các nền dân chủ chuyển đổi như Việt Nam. Tuy nhiên, với những trở ngại, khó khăn như đã trình bày ở trên, việc thành lập Tòa án hiến pháp ở Việt Nam chắc chắn sẽ cần nhiều thời gian cùng với những chuyển biến tích cực về dân chủ và pháp quyền. Hoặc là trao quyền bảo hiến cho các tòa án tư pháp. Thực ra, việc trao quyền cho các tòa án tư pháp không được ủng hộ lắm trong quá trình làm Hiến pháp năm 2013, tuy nhiên, chính những điểm mới của Hiến pháp có thể đem lại những triển vọng cho việc trao quyền bảo hiến cho Tòa án tối cao. Vấn đề cần nghiên cứu là làm sao để xác đinh vị trí vai trò và thẩm quyền tài phán của các tòa án (Tòa án hiến pháp, các tòa án hay Tòa án tối cao) phù hợp với mô hình tổ chức quyền lực nhà nước và hệ thống tư pháp ở nước ta hiện nay.

Giải pháp khả thi nhất là Quốc hội thành lập một Ủy ban Hiến pháp (thường trực hoặc lâm thời) có thể là một giải pháp để nâng cao hiệu quả hoạt động bảo hiến và phù hợp với Hiến pháp 2013. Ủy ban là một thiết chế thuộc vào Quốc hội, có nhiệm vụ kiểm tra, phán xét các vi phạm Hiến pháp hoặc tư vấn cho Quốc hội trong hoạt động bảo hiến. Các hoạt động kiểm tra, giám sát, xem xét hành vi vi phạm Hiến pháp được thực hiện bởi các tiểu ban chuyên trách. Trên cơ sở báo cáo của các tiểu ban, Ủy ban họp toàn thể để xem xét và đưa ra phán quyết. Các phán quyết của Ủy ban được thực 
hiện trên cơ sở biểu quyết theo đa số. Giá trị phán quyết của Ủy ban có giá trị bắt buộc hoặc tham vấn. Giải pháp thành lập Ủy ban Hiến pháp thuộc Quốc hội có tính khả thi cao, bởi nó không làm thay đổi nguyên tắc tổ chức quyền lực nhà nước ở nước ta, đặc biệt là nguyên tắc Quốc hội tối cao. Tuy nhiên, cũng phải nhấn mạnh, mô hình này khó đem lại hiệu quả, bởi vì nó vẫn chủ yếu là cơ chế trực thuộc và thực hiện chức năng giúp Quốc hội trong việc thực hiện nhiệm vụ bảo hiến.

3.5. Lời nói đầu khẳng định vị thế của người dân trong việc xây dựng và thực thi Hiến pháp. Điều này thể hiện sự thay đổi lớn về tư duy lập hiến trong việc khẳng định quyền lập hiến thuộc về nhân dân. Thực tế, trong quá trình làm Hiến pháp năm 2013, chưa bao giờ trong lịch sử nước ta có được cuộc thảo luận sửa đồi Hiến pháp rộng rãi và thực chất với nhiều hình thức đa dạng như vậy. Chính thông qua việc thảo luận sửa đổi Hiển pháp, nhận thức của xã hội, người dân về Hiến pháp và quyền con người, quyền công dân được nâng cấp rất nhiều. Ngay sau khi Hiến pháp năm 2013 được ban hành, Quốc hội cũng đã ban hành và thực hiện chủ trương phổ biến, tuyên truyền Hiến pháp. Trong một bối cảnh rộng hơn, Nhà nước và xã hội ngày càng coi trọng, đề cao pháp luật trong đời sống chính trị - xã hội. Hàng năm, ngày Pháp luật $9 / 11$ đều được tổ chức với các ý nghĩa: Tôn vinh Hiến pháp, pháp luật, đề cao giá trị của Hiến pháp, pháp luật trong nhà nước pháp quyền, giáo dục ý thức thượng tôn pháp luật cho mọi người trong xã hội. Dưới góc độ quyền con người, thực tiễn trong những năm gần đây cũng cho thấy sự quan tâm, nhận thức ngày càng được nâng cao của toàn xã hội về quyền con người. Giáo dục nhân quyền ở nước ta đã có những tiến triển nhanh chóng trong hai thập kỷ qua góp phần thúc đẩy nhận thức về quyền trong xã hội.

3.6. Để nâng cao nhận thức của người dân về Hiến pháp, về quyền con người, quyền cơ bản của công dân, điều quan trọng nhất là phải có chiến lược tuyên truyền, giáo dục Hiến pháp, giáo dục nhân quyền để người dân hiểu đầy đủ các giá trị của Hiến pháp, nhân quyền mang đến cho các công dân, cộng đồng, quốc gia. Ngoài ra cũng cần phải đổi mới công tác tuyên truyền, giáo dục Hiến pháp, nhân quyền để nâng cao hiệu quả, chất lượng của các hoạt động này. Cần phải phát huy được sự tham gia của cả hệ thống chính trị, toàn dân trong hoạt động tuyên truyền, giáo dục Hiến pháp, nhân quyền.Hiệp hội về Hiến pháp và Hiệp hội tổ chức nhân quyền quốc gia nên được thành lập để thúc đẩy công tác bảo vệ cũng như tuyên truyền giáo dục về Hiến pháp, nhân quyền.

3.7. Ngoài công tác tuyên truyền, giáo dục thì các hoạt động trợ giúp pháp lý, hỗ trợ người dân, đặc biệt các nhóm yếu thế trong xã hội ngày càng được quan tâm. Luật trợ giúp pháp lý được sửa đổi năm 2017 nhằm thúc đẩy hoạt động trợ giúp pháp lý cho người nghèo và một số đối tượng chính sách khác. Cần tạo cơ chế để khuyến khích và thúc đẩy hơn nữa vai trò của các tổ chức hành nghề luật, các tổ chức xã hội trong công tác tuyên truyền, thúc đẩy nhận thức về Hiến pháp, pháp luật và nhân quyền.

\section{Lời cảm ơn}

Bài viết này là một phần trong Dự án nghiên cứu về "Công lý và quyền tiếp cận công lý ở Việt Nam" (Mã số 505.01-2017.01) do Quỹ Khoa học và Công nghệ quốc gia Việt Nam (NAFOSTED) tài trợ.

\section{Tài liệu tham khảo}

[1] Vũ Công Giao, Tiếp cận công lý và các nguyên lý của nhà nước pháp quyền, Tạp chí Khoa học ĐHQGHN, Luật học 25 (2009) 188-194.

[2] Đặng Minh Tuấn (Chủ biên), Bảo hiến và vấn đề bảo vệ quyền con người (Sách chuyên khảo), NXB Tư pháp, Hà Nội, 2015, tr.46-49.

[3] Đặng Minh Tuấn, Thiết lập tài phán hiến pháp: Xu thế thế giới và tương lai cho Việt Nam, trong Sửa đổi, bổ sung Hiến pháp 1992 - Những vấn đề lý luận và thực tiễn. Tập 2 Quyền con người, quyền công dân, chế độ kinh tế, bảo hiến và một số vấn đề khác" (Sách chuyên khảo), do Phạm Hồng Thái, Nguyễn Sĩ Dũng, Nguyễn Đăng Dung, Vũ Công Giao, Hoàng Minh Hiếu, Đặng 
Minh Tuấn đồng chủ biên, NXB Hồng Đức, Hà Nội, 2012, tr.322-355.

[4] Ban Biên tập Dự thảo sửa đổi Hiến pháp năm 1992, Một số vấn đề cơ bản của Hiến pháp các nước trên thế giới, NXB Chính trị Quốc gia, 2012, tr.259-273.

[5] Ban Biên tập Dự thảo sửa đổi Hiến pháp năm 1992, Mô hình tổ chức và hoạt động của Hội đồng Hiến pháp ở một số nước trên thế giới (Sách chuyên khảo), NXB Chính trị Quốc gia Hà Nội, Hà Nội, 2013.

[6] Đặng Minh Tuấn, Khiếu kiện Hiến pháp của người dân: Kinh nghiệm một số nước và một số kiến nghị cho Việt Nam, Kỷ yếu Hội thảo "Sự tham gia của nhân dân vào quy trình lập hiến", Viện Chính sách công và Pháp luật tổ chức, NXB ĐHQGHN công bố, Hà Nội, năm 2013.

[7] Đặng Minh Tuấn, Chế định quyền con người, quyền cơ bản của công dân trong Hiến pháp năm 2013: Vấn đề sửa đổi và những điểm mới cơ bản, trong "Thực hiện các quyền hiến định trong Hiến pháp năm 2013" (Sách chuyên khảo), do Trịnh Quốc Toản, Vũ Công Giao đồng chủ biên, NXB Hồng Đức, 2015, tr.74-82.

[8] Đặng Minh Tuấn, Quy trình, thủ tục bảo hiến theo Hiến pháp năm 2013: Thực trạng và yêu cầu hoàn thiện pháp luật về quy trình, thủ tục bảo hiến, Hội thảo "Cơ chế bảo vệ Hiến pháp theo Hiến pháp năm 2013", Viện Nhà nước và Pháp luật tổ chức, TP. Hồ Chí Minh, tháng 10/2014.

[9] Nguyễn Đăng Dung, Vi phạm Hiến pháp và các loại hình vi phạm hiến pháp, Tạp chí Nghiên cứu lập pháp, Số 09 (216), Tháng 5/2011.

[10] "Nhiều người dân vẫn chưa biết Hiến pháp mới như thế nào", http://vneconomy.vn/thoi-su/nhieunguoi-dan-van-chua-biet-hien-phap-moi-the-nao20140518031042547.htm, truy cập ngày 18/3/2018.

[11] Mai Hồng Quỳ, "Để Hiến pháp mới đi nhanh vào cuộc sống", http://baochinhphu.vn/Tim-hieuHien-phap-nuoc-CHXHCN-Viet-Nam/De-Hienphap-moi-di-nhanh-vao-cuoc-song/231670.vgp;

[12] Minh Hòa/VOV online, "Để người dân tiếp cận và hiểu Hiến pháp", https://vov.vn/chinh-tri/demoi-nguoi-dan-tiep-can-va-hieu-hien-phap310073.vov, truy cập ngày 18/3/2018.

[13] Nguyễn Đăng Dung, Trịnh Quốc Toản, Đặng Minh Tuấn (Đồng chủ biên), Bình luận Khoa học Hiến pháp Nước Cộng hòa Xã hội Chủ nghĩa Việt Nam năm 2013, NXB Chính trị Quốc gia, Hà Nội, 2016.

[14] Kỷ yếu Hội thảo "Giải thích Hiến pháp, Luật", Viện nghiên cứu Lập pháp UBTVQH tổ chức, Hà Nội, tháng 3/2006.

\title{
Access to Justice and the Reform of the Constitutional Protection Mechanism in Vietnam
}

\author{
Dang Minh Tuan \\ VNU, School of Law, 144 Xuan Thuy, Cau Giay, Hanoi, Vietnam
}

\begin{abstract}
Constitutional protection is a topic that has been discussed extensively in our country in recent years, but has not been studied in terms of access to justice. This article analyzes some of the general issues of the relationship between access to justice and constitutional protection, thereby assessing constraints, prospects and solutions for securing access to justice through constitutional protection mechanism in Vietnam.
\end{abstract}

Keywords: Access to justice, constitutional protection, judicial review, Vietnamese Constitution. 